\title{
Current community based ecotourism practices in Menz Guassa community conservation area, Ethiopia
}

\author{
Endalkachew Teshome $\cdot$ Fikadu Shita $\cdot$ Firdyiwok Abebe
}

Published online: 27 March 2020

(C) The Author(s) 2020

\begin{abstract}
Ethiopia is a country which is endowed with an enormous assemblage of ecotourism resources. This makes it a suitable country for the development of community based ecotourism endeavors, to enhance conservation practices, and improve indigenous livelihood. This study aimed to assess the current community based ecotourism practices in Menz Guassa Community Conservation Area. A cross-sectional study design combining both quantitative and qualitative methods was used to describe the existing community based practices. A total of 223 study participants completed a questionnaire, and the data received were analyzed by using SPSS Version 20. Findings revealed that relatively, Menz Guassa offers higher natural tourism activities (i.e. trekking, bird and wildlife watching, climbing) with 4.35 mean, compared to cultural activities. Indigenous community leaders were capable of operating and managing community based ecotourism businesses effectively, and inspiring individuals from the local population to
\end{abstract}

E. Teshome $(\bowtie) \cdot$ F. Abebe

Department of Tourism Management, University of Gondar, P.O. Box 196, Gondar, Ethiopia

e-mail: endalkay@gmail.com

F. Abebe

e-mail: abebe.fird81@gmail.com

F. Shita

North Shewa Culture, Tourism and Sport Department, Debreberhan, Ethiopia

e-mail: shitafikadu2007@gmail.com participate in the tourism business. The income generating from community based ecotourism practices contributes to natural resource conservation, cultural preservation, and livelihood improvement. The current community organization specifically established for the management and operation of community based tourism was effective. Community based ecotourism practices to this destination were respectful of the rights, cultural and spiritual practices of the indigenous community.

Keywords Community practices - Conservation · Menz Guassa

\section{Introduction}

Ethiopia is a country which is endowed with the vast array of ecotourism resources, cultural, historical, archaeological and natural (Amare 2015; Tesfaye 2017; Eshetu 2014). Moreover, strong traditions have long contributed to Ethiopia's material wealth by producing illuminated parchment manuscripts, pottery, basketry, leatherwork, woodwork, metalwork, and jewelry, and making it perhaps a perfect country for the development of community based ecotourism ventures (Teshome et al. 2018; Teshome and Demissie 2018). However, this ample tourism resources are not yet fully developed and the tourism industry is still in its infancy (Amare 2015). Menz Guassa Community 
Conservation Area is an example of this stunning tourism potential, and has been used for millennia with unrestricted access for fuel wood collection, livestock grazing, fodder grass and medicinal plant collection by the surrounding communities (Ashenafi et al. 2012). For more than 400 years, people in Menz have been able to regularly use the resources for valuable grazing, as well as collecting grass for thatched roof cover, all without noticeable impact (Ashenafi et al. 2005). However, currently the rapid population growth is threatening the traditional management system, creating conflicts among impoverished local households, and endangering the principle of ecosystem conservation. The Menz Guassa Community Conservation Area is critically important for both biodiversity conservation and poverty alleviation, and is also home to an ancient common property resource management system (Ashenafi and Leader-Williams 2005).

The majority of the households in Mena Guassa are categorized as chronically food insecure, and the host community is highly dependent on food security programs (Mandefero and Tilaye 2019; UNDP 2012). Deforestation and inappropriate land use practices have depleted resources resulting in low productivity, and a high rate of population growth has caused rural households to use natural resources extensively and focus on ecologically sensitive areas (Ashenafi and Leader-Williams 2005). To reduce these environmental impacts and to improve the livelihood of the indigenous people, a community based ecotourism business project was established in 2008. Since 1980 ecotourism has played a significant role for the conservation, protection and sustainable use of biodiversity by creating off-farm job opportunities for indigenous communities in host countries (Scheyvens 1999; UNWTO 2013).

Some researchers have done studies on community based ecotourism in different parts of Ethiopia, mainly focused on surveying potential for CBETD and the value of ecotourism for wildlife conservation, economic development opportunities, as well as the challenges of community based natural resource management (Amare 2015; Tesfaye 2017; Teshome et al. 2018; Teshome 2018; Bekele et al. 2017; Berhanu and Teshome 2016; Meskele et al. 2016; Aynalem and Simane 2016; Fentaw 2016; Gebreigziabher 2015; Asfaw 2014). None of those scholars touched upon the Menz Gussa community conservation area community based ecotourism practices. Therefore, to fill up the gap, the aim of this research was to identify the current community based ecotourism practices in Menz Guassa Community Conservation Area.

\section{Literature review}

The development of the concept of community ecotourism grew, according to Hetzer, as a result of dissatisfaction with governments' and society's negative approach to development, especially the social dimension (Denman 2001). The concept of community based tourism emerged out of the concept of sustainable community tourism referring to a type of tourism that does not damage social, environmental and cultural systems of the community (Hardy and Beeton 2001). It is new types of tourism, alternative and soft tourism, which sought to bridge the gap between tourist and host, were promoted in the forms of tourism development projects in developing countries beginning in the 1970s (Pearce 1992). Community based tourism, refers to a kind of tourism which provides high levels of community participation under sustainability approach (Timmothy 2002). It is a conservation tool for biodiversity and natural resources, with implications for rural development and poverty alleviation, and maintaining biodiversity (Denman 2001; Kiss 2004; Teshome et al. 2015). Tourism can be an important source of income and improved standards of life only if; economic, social and ecological goals are maintained in balance (Fennell 2001). Particularly community based ecotourism is also a source of economic diversification for rural communities, thus empowering them (Kiss 2004). Moreover, ecotourism is a tourism activity that involves the preservation and conservation of nature, providing infrastructure and facilities in the tourist attraction area. Globally there are a number of different terms used for very similar activities. For example in Latin America the term rural tourism is often used, alongside community based tourism, in parts of Asia, ecotourism is often delivered via community based tourism, in part of Africa the term of community based ecotourism as community based tourism. While, all of them a set of principles as well as a market segment of sustainable tourism (Asker et al. 2010). 
Prior researchers mentioned that ecotourism sometimes called community based ecotourism is a segment of sustainable tourism has significant contributions for the protection of environment and the growth of economy; high degree of community involvement and fair share of benefits in tourism development; improvement the quality of life of the host community; provide a high quality of experience for the visitor; maintain the quality of the environment and decision making process of various stakeholders (Teshome 2018; Denman 2001; Kiss 2004; Fennell 2001; Coria and Calfucura 2012; Razzaq et al. 2012; Giampiccoli and Saayman 2017; Kidane 2012). Community-based ecotourism refers more specifically to tourism activities or enterprises that involve local communities; it operates in their lands, and is based on their cultural and natural assets and attractions (Nelson 2004; Mensa 2017).

Community based tourism stresses out the fundamentality of active participation of local people to the tourism development process so that by local control negative social, cultural, environmental and economic effects can be minimized and further implementation of tourism initiatives will lead to maximization of local benefits (Teshome et al. 2015; Sakata and Prideaux 2013). In this segment of ecotourism, local community has substantial control over, and involvement in its development and management, and a major proportion of the benefits remain within the community (Denman 2001). Local community participation in community based ecotourism enabling them to take part in decision making process to generate and fair distribution of economic (Yanes et al. 2019), and social benefits of tourism can be owned, managed and internal collaboration and social cohesiveness can be established throughout the local community (Responsible Ecological Social Tour (REST) 1997; Stone and Stone 2011).

Kiss (2004) notes that community based ecotourism provides three main benefits: improved community development stimulated by increased income; natural resource management and sustainability; and increased value in the tourism product. In even more simplistic terms, it is a grass-roots process whereby tourism is planned, implemented, managed by and benefits the local community in which tourism occurs (Giampiccoli and Saayman 2017). At its hub, community based ecotourism is a paradigm shift away from the top-down approach of large-scale tourism where policies and decision-making occur at the top of the stakeholder pyramid, and instead allows the local community to direct itself (Razzaq et al. 2012; Strydom and Mangope 2018).

\section{Method}

Description of the study area

Menz Guassa Community Conservation Area is located in the central highlands of Ethiopia in Amhara National Regional State, and has seen the reintroduction of an indigenous land use system to safeguard its important biodiversity and secure the long-term livelihoods of its local residents (UNDP 2012). This area, covering over $110 \mathrm{~km}^{2}$ at an altitude of 3200-3700 m above sea level, is an important component of the Afro-Alpine habitat of Ethiopia falling within the conservation international biodiversity 'hotspot' of the Ethiopian highlands (Ashenafi et al. 2012).

Based on the 2007 national census conducted by the Central Statistical Agency of Ethiopia (CSA), this district has a total population of 120,469 , of whom 58,827 are men and 61,642 women; 11,055 or $9.18 \%$ are urban inhabitants (CSA 2007). Crop farming and livestock husbandry are the main sources of livelihood. However, environmental degradation in the study area is closely related to food insecurity due to declining farm productivity. At high altitude, the wet season is characterized by a combination of rainfall, frequent fog and occasional snow. The mean annual rainfall of the area is $860 \mathrm{~mm}$, while the temperature monthly mean ranges from 5.2 to $19.5^{\circ} \mathrm{C}$ (Ashenafi and Leader-Williams 2005) (Fig. 1)

The Guassa Area is found on the edge of the Great Rift Valley that divides the Ethiopian highlands into two major topographic features (EWNHS 1996), and this escarpment on the eastern side of the Guassa Area forms a continuous north-south wall, with sheer cliffs over $1 \mathrm{~km}$ long. This dramatic cliff formation has provided the area with spectacular scenic beauty and stunning views across the lowland areas of Yifat and the Great Rift Valley, up to the Awash Valley in the Afar Region (GMP 2007). This spectacular scenic beauty combined with stunning views could attract nature tourists from all over the globe. 


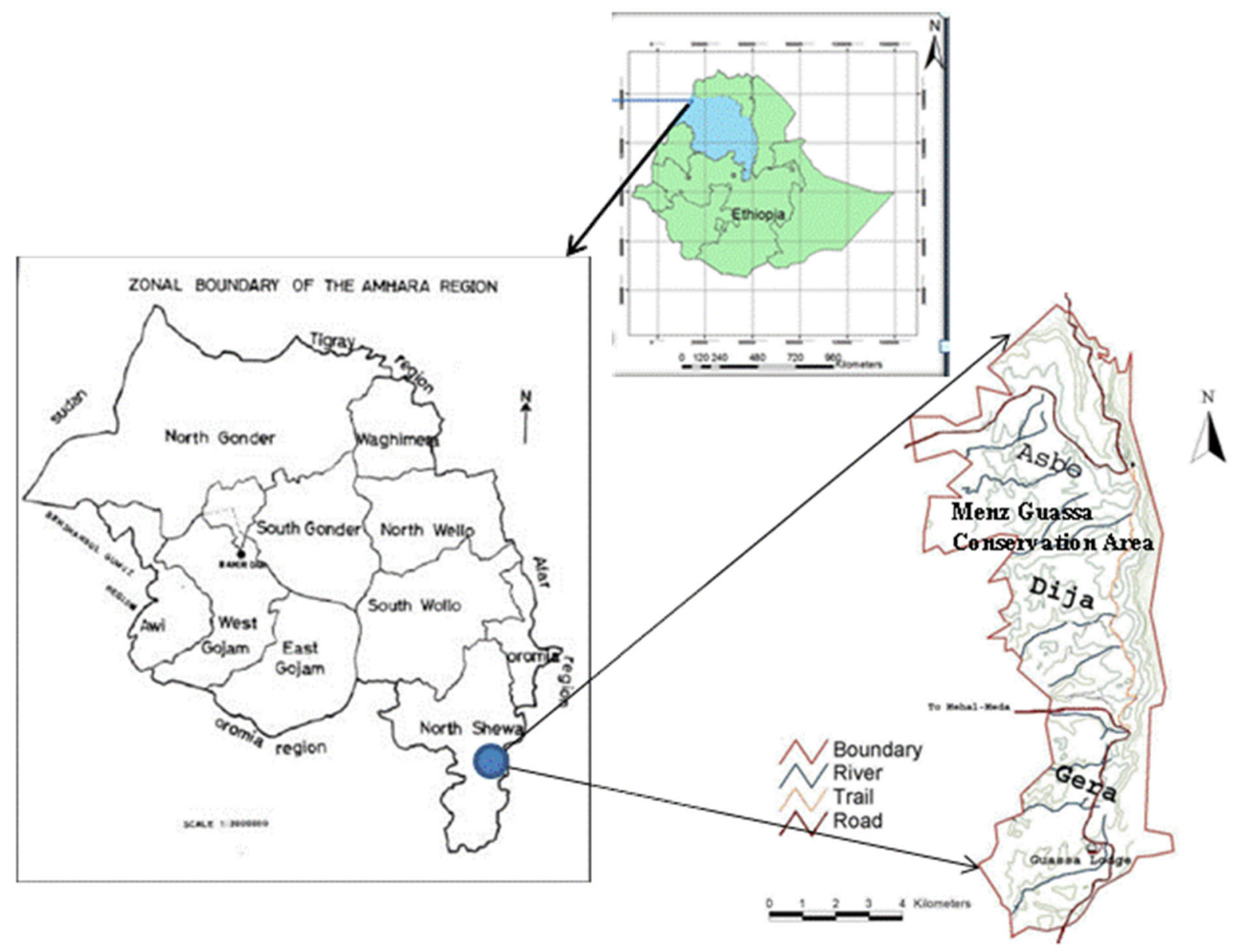

Map of the study area

Fig. 1 Map of the study area. Source: Adopted from FZS (2007)

According to Ashenafi et al. (2005), the vegetation of the Guassa area is characterized by high altitude Afro-alpine vegetation, with different habitat types namely, Euryops Alchemilla shrubland (22\%), Festuca grassland (20\%), Euryops-Festuca grassland or Mima mound (16\%), and Erica moorland (10\%). The area derives its name from the so-called 'Guassa grass', which comprises four species of Festuca highly valued by the local community, among other uses, for thatching and manufacturing of household and farm implements (UNDP 2012). The area is rich in biodiversity and contains several endemic and threatened species of flora and fauna, including Ethiopian wolves and gelada baboons (EWNHS 1996; Wodaj et al. 2016). The occurrence of several endemic species may also attract tourists from all over the world.

A number of endemic and range-restricted species of mammals and birds are found in this unique habitat type in the Guassa Area (Aynalem and Afework 2018). The Guassa area is home to several mammalian species of the endemic mammal fauna of Ethiopia, such as the Ethiopian wolf, Gelada Baboon (Theropithecus Gelada) and Abyssinian hare (Lepus starcki). There are about 111 bird species, of these $14(48 \%)$ are endemic to Ethiopia. The area also serves as a wintering ground for 38 species of palearctic and intra-African migrant birds (EWNHS 1996; Aynalem and Afework 2018). The availability of these unique species could attract more visitors to this community based ecotourism destination. 


\section{Research design}

Cross sectional with a descriptive research design was employed, which uses a combination of qualitative and quantitative or mixed approach. This is because, when research is conducted in natural settings, supplementing the quantitative with qualitative method helps to investigate, interpret and measure real life events, community based ecotourism practices and complex socio-cultural aspects of the livelihoods in the study area/GCCA (Knerr 2008).

\section{Population of the study}

The target population of this study was 9835 household members who are beneficiaries of the community based ecotourism business project of Menz Guassa community conservation area (UNDP 2012). Additionally, Governmental and Non-Governmental organizations who work in the Menz Guassa conservation area, the Menz Guassa community conservation area experts, and the Guassa tourism council were included.

Sampling technique and sample size determination

Both probability and non-probability sampling methods were employed. The selected sampling techniques were stratified, simple random and purposive samplings. These techniques are considered appropriate for the complexity of the Menz Guassa community conservation area.

Sampling techniques for quantitative method

In order to select the kebeles stratified sampling, and to select respondents to complete the questionnaire, simple random sampling techniques were used. There were nine kebeles $^{1}$ in the study area (Kuledeha, Gedenbo, Alfamder, Chare, Gragn, Dargegn, Yedi, Tesfomentir and Keyewula). Target population of the study area is 9835 head of households (Kuledeha 1047, Gedenbo 1425, Alfamder 725, Chare 1176, Gragn 1195, Dargegn 1086, Yedi 798, Tesfomentir 1043 and Keyewula 1317). Each kebele has a different number of participants in order to ensure equal representation, as each sample kebele has a different number of households. Sample size is therefore in proportion to the population of each of the selected kebeles. The actual respondents of the study were randomly selected from the identified kebeles. If the population was less than 10,000 , sample size was determined as follows (Aboobakur and Samarakoon 2019).

$n s p z=\frac{n}{1+\left(\frac{n}{s p z}\right)}$

$\mathrm{nspz}=$ minimum sample size when the population is small; $\mathrm{n}=$ minimum sample when the population is large; $\mathrm{spz}=$ population size (small population)

$n s p z=\frac{228}{1+\left(\frac{228}{9835}\right)}=\frac{228}{1+(0.0232)}=\frac{228}{1.0232}=223$.

Sampling size in selected kebeles

For calculating the sample size of each kebele the researcher used the formula of (Kothari 2013)

$n 1=(N 1 / N) n$

where $\mathrm{n} 1=$ number of participants in each strata; $\mathrm{N} 1$ = total population of each strata; $\mathrm{N}=$ total population; $\mathrm{n}=$ sample size of total population (Table 1).

Sampling techniques for qualitative method

Non-probability sampling was selected due to its practicality of identifying issues relevant to the study, rather than representativeness of the population. Purposive sampling was employed to select key informants such as NGOs who works in Menz Guassa conservation area, the Menz Guassa community conservation area experts, and the Guassa tourism council. All three groups of key informants were selected purposely with respect to their roles in resource conservation and management activities, and ecotourism development activities, as well as their knowledge and experience on the subject of community based ecotourism tourism practices. The selection of samples for the interview stressed the quality of respondents and their ability to answer the questions with rich and relevant information.

${ }_{1}$ Small unit of Government administrative structure. 
Table 1 Sample size proportion in selected kebeles. Source: Guassa Office 2018

\begin{tabular}{lclc}
\hline Kebele & Total population & Proportion & Sample taken \\
\hline Kuledeha & 1047 & $(1047 / 9835) * 223$ & 24 \\
Gedenbo & 1425 & $(1425 / 9835) * 223$ & 32 \\
Alfamder & 725 & $(725 / 9835) * 223$ & 16 \\
Chare & 1176 & $(1176 / 9835) * 223$ & 27 \\
Gragn & 1195 & $(1195 / 9835) * 223$ & 27 \\
Dargegn & 1086 & $(1086 / 9835) * 223$ & 25 \\
Yedi & 798 & $(798 / 9835) * 223$ & 18 \\
Tesfomentir & 1043 & $(1043 / 9835) * 223$ & 24 \\
Keyewula & 1317 & $(1317 / 9835) * 223$ & 30 \\
Total & 9835 & $(9835 / 9835) * 223$ & 223 \\
\hline
\end{tabular}

Methods of data analysis

The qualitative data and free responses from openended in-depth interviews were characterized based on recognized commonalities and analyzed thematically in line with research questions. The qualitative data were analyzed using techniques based on procedures in qualitative data analysis. The quantitative information was analyzed first using descriptive and then inferential techniques of data analysis. In the process, the completed questionnaires were coded and the data was analyzed using SPSS Version 20.0. SPSS for windows was chosen because it is a powerful statistics program that can run most bivariate and multivariate statistics, and interpreted to show a detailed picture of the existing situation in the study area. In descriptive analysis, the frequency distribution, percentage and average mean were used.

\section{Result and discussion}

General characteristics of households

Among 214 sample households' respondents, 69.6\% were male and $30.4 \%$ were female. Of the three age categories, a majority (72.9\%) of the household respondents were aged between 18 and 64 (Table 2). Such age groups are believed to have ample experience in identifying the comprehensive information of community based ecotourism practices of the area. $25.2 \%$ were above the age of 65 years, and $1.9 \%$ below the age of 18 years. The data reveal that on average the households are middle age category. Regarding marital status of the respondents, 97
(45.3\%) were married, and 78 (36.4\%) were single. Thirty-nine (18.2\%) were either divorced or widowed. Both divorced or widowed and single respondents may exert higher pressure on the forest due to lack of agricultural land for their livelihoods.

Table 2 also reveals the respondents' educational status: $108(50.5 \%)$ of the respondents had attended adult education and church schools, 61 (28.5\%) had attended formal education, while 45 (21\%) study participants had no schooling.

Source of households income distribution

In terms of occupation, the majority $(82.2 \%)$ of the households are engaged in subsistence farming and cereal crop production; common grains produced were barley and wheat (Fig. 2). The local communities were imposing extreme pressure on the forest resources for agricultural activities, since the majority of the population are farmers (Ashenafi et al. 2012).

\section{Tourism potential and practices of community based ecotourism on MGCCA}

\section{Potential natural tourism resources in MGCCA}

$193(90.2 \%)$ of respondents agreed or strongly agreed that "MGCCA offers natural tourism activities such as trekking, bird and animal watching, and climbing;" however, another 4 (1.9\%) of respondents disagreed with the availability of those potentials (Table 3 ). From open ended questions, the researchers found that respondents who agree on the tourism attractions were participating in different activities including tour 
Table 2 Sex, age, marital status and educational background distribution. Source: Survey data, 2018
General characteristics of sample households

Sex

Male

Female

Total

Age

Below 18

$18-64$

Above 65

Total

Marital status

Married

Single

Widowed

Divorced

Total

Educational background

Primary school (1-8)

Secondary school (9-12)

College graduate and above

Church education

Adult education

No. schooling

Total
Frequency

Percent

149

69.6

65

214

30.4

100

4

1.9

156

72.9

54

25.2

214

100

97

45.3

78

36.4

30

14

9

4.2

214

100

49.0

22.9

7.9

3.7

4.1

1.9

27.0

12.6

81.1

37.9

44.9

21

214

Fig. 2 Sources of household income of the study participants. Source: Own survey data, 2018

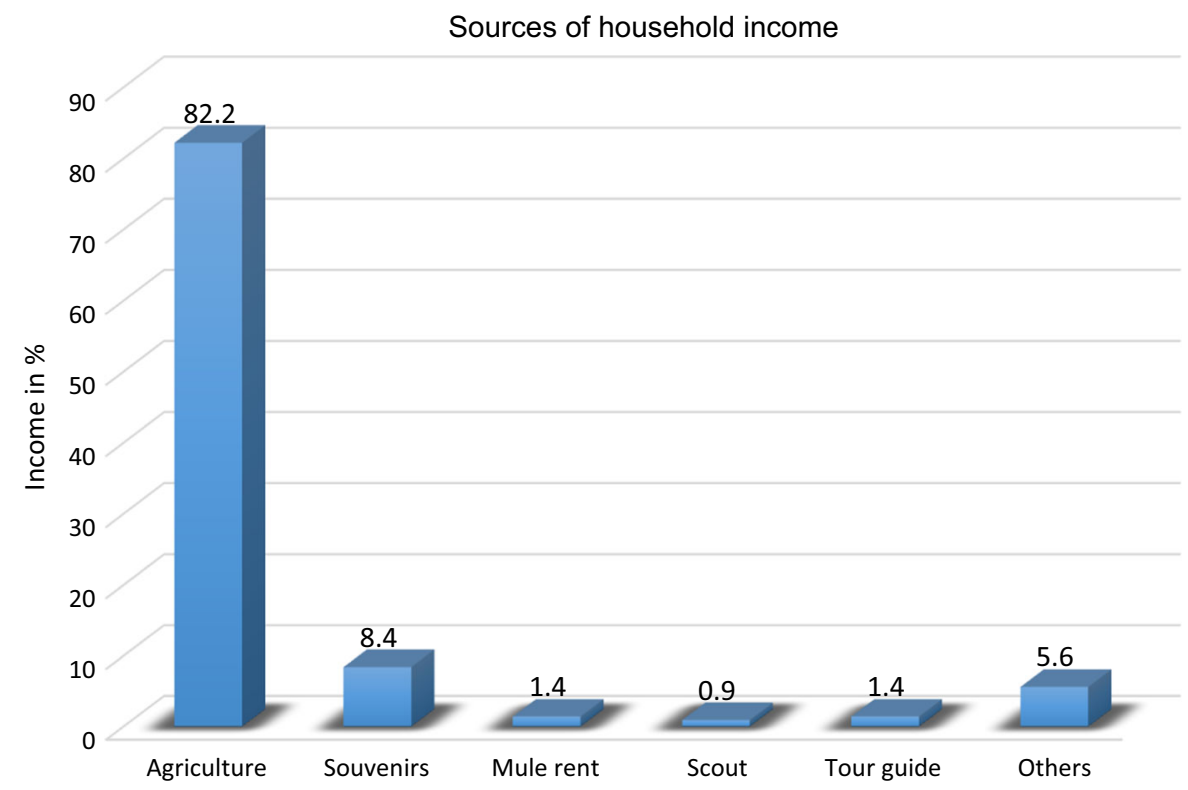


Table 3 HHs level of agreement on tourism potentials for the development of CBET. Sources: Survey data, 2018

\begin{tabular}{|c|c|c|c|c|c|c|c|c|c|c|c|}
\hline \multirow[t]{2}{*}{ Variables } & \multicolumn{2}{|l|}{ SA } & \multicolumn{2}{|l|}{ A } & \multicolumn{2}{|l|}{$\mathrm{U}$} & \multicolumn{2}{|l|}{ D } & \multicolumn{2}{|l|}{ SD } & \multirow[t]{2}{*}{ Mean } \\
\hline & $\mathrm{F}$ & $\%$ & $\mathrm{~F}$ & $\%$ & $\mathrm{~F}$ & $\%$ & $\mathrm{~F}$ & $\%$ & $\mathrm{~F}$ & $\%$ & \\
\hline $\begin{array}{l}\text { MGCCA offer natural tourism activities (i.e. trekking, bird and } \\
\text { animal watching, climbing) }\end{array}$ & 104 & 48.6 & 89 & 41.6 & 17 & 8 & 0 & 0 & 4 & 1.9 & 4.35 \\
\hline $\begin{array}{l}\text { MGCCA offer cultural activities (i.e. traditional local dance, } \\
\text { learning local product and souvenir producing) }\end{array}$ & 14 & 6.5 & 51 & 23.8 & 92 & 43 & 36 & 16.8 & 21 & 9.8 & 3.0 \\
\hline
\end{tabular}

guiding, mule renting, scouting, producing and selling crafts, and also providing services to tourists when trekking, bird and animal watching.

Moreover, triangulated qualitative information/data obtained from the interviews with key informants and field observation of tourism activities in the Menz Guassa Community Conservation Area also revealed that the Menz Guassa landscape is adulated, and has numerous spectacular views of escarpments which can attract mountain trekking, along with it being the home of over 114 bird species (Aynalem and Afework 2018).

\section{Potential cultural tourism resources in MGCCA}

$65(30.3 \%)$ of respondents agreed or strongly agreed that "MGCCA offer cultural activities (i.e. traditional local dance, learning local product and souvenir producing. Although there is visiting of traditional villages, watching traditional dance, attending and watching of religious and public festivals, with offerings of traditional food and drinks in Menz Guassa Community Conservation Area, the majority of the respondents didn't recognize these practices. Moreover, field observation confirmed that the Menz Guassa area has huge cultural resources potential, the local community producing illuminated parchment manuscripts, pottery, basketry, leatherwork, woodwork, metalwork, and jewelry for a local souvenir owner, while the current community based ecotourism project has not given attention to this cultural side.

The triangulated qualitative information/data obtained from the key informant interviews revealed that low level of community awareness was the major problem for the last five years. At a result the resources are being managed traditionally by the local community only for different uses, including grazing livestock, collecting firewood, and cutting Guassa grass for various purposes (Ashenafi et al. 2012).
Respondent level of agreement on current tourism practices in MGCCA

\section{CBET contribution for biodiversity conservation}

$195(91.1 \%)$ of respondents agreed or strongly agreed that "CBET helps to conserve biodiversity;" however, another $4(1.9 \%)$ of respondents disagreed. This may be a result of the old traditional resources management and biodiversity conservation practices in the area (Ashenafi et al. 2005; Ashenafi and Leader-Wiliams 2006). Likewise, community based ecotourism can reduce local threats (i.e. agricultural encroachment, unsustainable harvesting of wild plants and animals, and killing wildlife that threatens peoples' crops, their livestock or themselves (Kiss 2004). The triangulated qualitative information obtained from key informants' interviews revealed that low level of community awareness was the major problem in the areas, a finding also supported by previous scholars (UNDP 2012; Kothari 2013).

\section{CBET contribution for livelihood income generation option}

$154(71.9 \%)$ of respondents agreed or strongly agreed that "CBET creates livelihood income generating options;" however, 53 (24.8\%) were undecided. According to our field observation local communities generate income from tourist service deliveries such as mule renting, souvenir product selling, tourist guiding, providing food and beverages for tourists, and from non tourist activities such as grass selling. However, community based ecotourism has been known as a tool for poverty reduction and for improvement in the livelihood of local people (Asfaw 2014; Mamo and Wube 2018).

Community members like women, men and the young are widely involved in decision making 
Fig. 3 Level of MGCCA local community agreement on CBET contribution. Source: Survey data, 2018
60

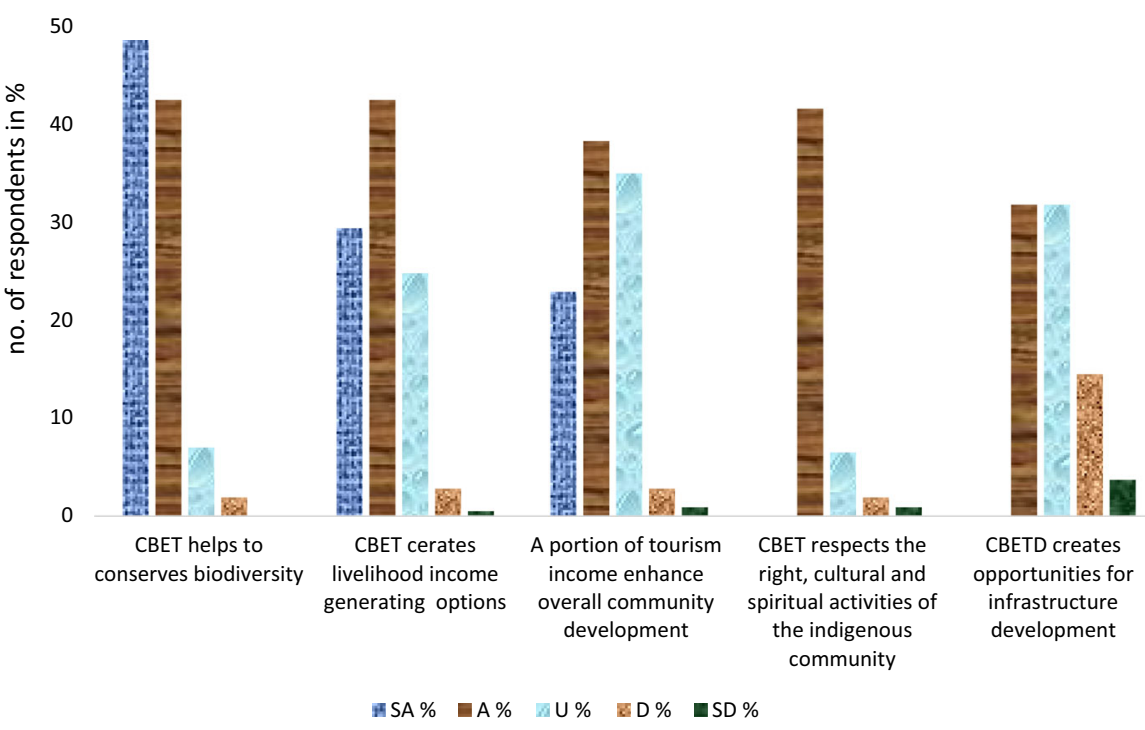

processes and participate greatly in CBET in the Menz Guassa area. In CBET the driving force is not purely income generation but also cultural and natural heritage conservation, as well as intercultural learning (Asker et al. 2010). The core aims of community based ecotourism is poverty alleviation in rural communities through the creation of sustainable income generating tourism activities, while conserving the delicate and sensitive ecological and cultural resources in their environments (Manu and Wuleka 2012). Community based ecotourism offers potential benefits to the individual and communities as a whole, in areas such as the creation of employment, foreign exchange earnings and improved welfare of local people, among others (Asker et al. 2010) (Fig. 3).

\section{Tourism income enhances overall community development}

$131(61.2 \%)$ of respondents agreed or strongly agreed that "a portion of tourism income enhances overall community development;" however, another 75 $(35 \%)$ were undecided. The is because ecotourism is always considered as a viable strategy for livelihood diversification and sustainable natural resource management in Ethiopia (Asfaw 2014; Kiss 2004).

CBET is thought to carry the promise to increase, promote and provide improved livelihoods for rural communities by supporting and enhancing rural community welfare through the generation of income from tourism. About $61.2 \%$ of respondents are agreed CBET contributed to the development of overall welfare of local people, about the contribution of CBET for their families. Key informants reported that local communities saved 3.5 million Ethiopian birr in the community saving fund account. Moreover, they are highly involved in different activities like providing guiding services, supplying accommodation, and offering catering services to enhance additional income for their own businesses (Aynalem and Simane 2016).

\section{CBET respects the right, cultural and spiritual activities of the indigenous community}

194 (90.7\%) of respondents in Menz Guassa community conservation area agreed or strongly agreed that "CBET respects the rights, cultural and spiritual activities of the indigenous community", however, another $6(2.8 \%)$ of respondents disagreed. 14 (6.5\%) were undecided. These result shows community based ecotourism gives high priority to the cultural, spiritual and religious rights of the host community. The triangulated qualitative information/data obtained from the interviews with key informants and field observation on the problems of biodiversity 
conservation in Menz Guassa Community Conservation Area also revealed that low level of community awareness was the major problem for the last 5 years (Ashenafi and Leader-Williams 2005; Kidane 2012).

\section{Community based ecotourism creates opportunities for infrastructure development}

$107(50 \%)$ of respondents agreed or strongly agreed that "CBETD creates opportunities for infrastructure development", however, and 68 (31.8\%) were undecided. Community based ecotourism does more than create a chain of activities to attract visitors, offering them an opportunity to interact with nature by developing infrastructures that can also be accessed by the local communities (Asker et al. 2010; Ambelu 2016).

\section{Leadership and management capacity}

Proficiency of community leader's to manage CBET

$177(82.7 \%)$ of respondents agreed or strongly agreed that "community leaders are capable of operating and managing CBET effectively" however, another 34 $(15.9 \%)$ were undecided. The researcher also understood how effective the community leaders are because Menz Guassa community conservation area has a long established and effective indigenous common resource management system (Qero) (Ashenafi and Leader-Williams 2005; Kidane 2012).

Proficiency of community leaders to inspire member participation in CBETD

$181(84.6 \%)$ of respondents agreed or strongly agreed that "community leaders are capable of inspiring members and local people to participate in CBETD" however, another 26 (12.1\%) were undecided. Triangulated key informant interviews also show community leaders inspiring the local communities through effective indigenous common resource management system (Qero). This traditional Qero system has been practiced for more than 400 years in the study area (Ashenafi and Leader-Williams 2005).
Implementation of rules and regulations

$92(42.9 \%)$ of respondents agreed or strongly agreed that "rules and regulations are strictly implemented for natural resource conservation and cultural preservation" however, another 102 (47.7\%) were undecided. In this regard Government rules and regulations refer to the agreements between the government and the community which help to protect and preserve both natural and cultural tourism resources in a sustainable way. This was derived with a top to bottom approach supported by the punishment of illegal acts on community based ecotourism. While the effective indigenous common resource management system (Qero) was properly implemented in the area (Ashenafi and Leader-Williams 2005; Ambelu 2016), the triangulated qualitative information obtained from the interviews with key informants and field observation of biodiversity conservation also revealed that violating government rules and regulations was the major problem for the last 5 years in Menz Guassa Community Conservation Area (Ambelu 2016).

Effectiveness of established community organization

$145(67.8 \%)$ of respondents agreed or strongly agreed that "the community organization specifically established for the management and operation of CBT is effective", however, another $65(30.4 \%)$ were undecided (Table 4). The area is managed by Guassa conservation council which has kebele and district level components and consists of both community and local government representatives. Guassa user communities live in nine kebeles (farmers' associations) adjacent to Guassa community conservation area (Ashenafi et al. 2005; Ashenafi and Leader-Williams 2005).

Government and NGOS support in CBET

$167(78.1 \%)$ of respondents agreed or strongly agreed that "Government and NGOs build the capacity of local people to participate in CBET". The triangulated qualitative information/data obtained from the interviews with key informants and field observation of the problems of biodiversity conservation in Menz Guassa Community Conservation Area show that support in 
Table 4 Management capacity in MGCCA. Sources: Survey data, 2018

\begin{tabular}{|c|c|c|c|c|c|c|c|c|c|c|c|}
\hline \multirow[t]{2}{*}{ Variables } & \multicolumn{2}{|c|}{ SA } & \multicolumn{2}{|l|}{ A } & \multicolumn{2}{|l|}{$\mathrm{U}$} & \multicolumn{2}{|l|}{$\mathrm{D}$} & \multicolumn{2}{|c|}{ SD } & \multirow[t]{2}{*}{ Mean } \\
\hline & $\mathrm{F}$ & $\%$ & $\mathrm{~F}$ & $\%$ & $\mathrm{~F}$ & $\%$ & $\mathrm{~F}$ & $\%$ & $\mathrm{~F}$ & $\%$ & \\
\hline $\begin{array}{l}\text { Community leaders are capable of operating and managing CBET } \\
\text { effectively }\end{array}$ & 85 & 39.7 & 92 & 43 & 34 & 15.9 & 3 & 1.4 & 0 & 0 & 4.21 \\
\hline $\begin{array}{l}\text { Community leaders are capable of inspiring members and local } \\
\text { people to participate in CBETD }\end{array}$ & 64 & 29.9 & 117 & 54.7 & 26 & 12.1 & 4 & 1.9 & 3 & 1.4 & 4.10 \\
\hline $\begin{array}{l}\text { Rules and regulations are strictly implemented for natural resource } \\
\text { conservation and cultural preservation }\end{array}$ & 26 & 12.1 & 66 & 30.8 & 102 & 47.7 & 18 & 8.4 & 2 & 0.9 & 3.45 \\
\hline $\begin{array}{l}\text { The community organization specifically established for the } \\
\text { management and operation of CBT is effective }\end{array}$ & 64 & 29.9 & 81 & 37.9 & 65 & 30.4 & 4 & 1.9 & 0 & 0 & 3.96 \\
\hline $\begin{array}{l}\text { Government and NGOs build the capacity of local people to } \\
\text { participate in CBET }\end{array}$ & 63 & 29.4 & 104 & 48.6 & 41 & 19.2 & 4 & 1.9 & 2 & 0.9 & 4.04 \\
\hline
\end{tabular}

Community Based Ecotourism has made valuable contributions to strengthening existing community based ecotourism business management and other community and environmental conservation. For example, NGOs such as us the Frankfurt Zoological Society play a major role in planning and management of biodiversity in MGCCA through CBET (Kidane 2012; Mamo and Wube 2018). These NGOs promote sustainable use and preservation of natural resources and also engage in education, public outreach, research and professional training (Kidane 2012).

\section{Conclusion}

Menz Guassa Community Conservation Area is endowed with substantial natural tourism resources that offer ecotourism activities such as trekking, bird and wildlife watching, and climbing. However, due to various challenges the local community is not benefitting from tourism. The current community based ecotourism practices in the study area contributes to biodiversity conservation, income generation, and livelihood improvement in the study area. The overall community based ecotourism practices also respect the rights, and the cultural and spiritual practices of the indigenous community. Community leaders are also capable of operating and managing visitors effectively, inspiring members and local people to participate in community based ecotourism development. The community organization specifically established for the management and operation of tourism business was efficient. Although Menz Guassa Community Based Conservation Area offers cultural activities (i.e. traditional local dance, learning how to produce local handcrafts, and souvenirs), the provision was very poor. Therefore, the committee members and the leaders should promote these valuable cultural tourism resources. To increase the flow of tourists and enhance the level of visitor satisfaction, the infrastructure and human resources management capacity should be improved. In addition, capacity building and training shall certainly be required. The rules and regulations of the community based ecotourism project should be strictly implemented for natural resource conservation and cultural preservation. Visitor's code of conduct should be prepared that outlines allowed activities and appropriate behaviour when interacting with wildlife and when visiting local communities, and should be provided on arrival to every tourist.

Acknowledgements I would like to thank the study participants and data collectors for their willingness to participate in the study. I also want to acknowledge my English brother Dr. Jonathan Douglas Hollins who lives on St Helena Island, in the South Atlantic Ocean for his kindly assistance in language editing of the final manuscript.

Funding Not applicable.

Data availability The datasets that are used and analysed anonymously during the current study are available from the corresponding author. If the publisher have reasonable request we can deliver it.

\section{Compliance with ethical standards}

Conflict of interest The authors declare that they have no conflict of interest.

Informed consent The informed consent obtained for this research was written from all participants, and this research is 
done only on socio-economic and opinion survey data and these data were tabulated and analysed anonymously and confidentially. Moreover, no any clinical data of any respondent was used in any section of this research.

Ethical approval Approval for this study was obtained from University of Gondar, College of Business and Economics, Department of Tourism Management with reference no. TMGT/ $225 / 12 / 2010$ on $04 / 09 / 2018$.

Open Access This article is licensed under a Creative Commons Attribution 4.0 International License, which permits use, sharing, adaptation, distribution and reproduction in any medium or format, as long as you give appropriate credit to the original author(s) and the source, provide a link to the Creative Commons licence, and indicate if changes were made. The images or other third party material in this article are included in the article's Creative Commons licence, unless indicated otherwise in a credit line to the material. If material is not included in the article's Creative Commons licence and your intended use is not permitted by statutory regulation or exceeds the permitted use, you will need to obtain permission directly from the copyright holder. To view a copy of this licence, visit http://creativecommons.org/licenses/by/4.0/.

\section{References}

Aboobakur, S., \& Samarakoon, M. B. (2019). Solid waste management in Kulhudhuffushi, Maldives; Most suitable solution for the Crisis Saifulla. International Journal of Environment, Agriculture and Biotechnology (IJEAB). https://doi.org/10.22161/ijeab.46.36.

Amare, A. (2015). Wildlife resources of Ethiopia: Opportunities, challenges and future directions: from ecotourism perspective-A review paper. Natural Resources, 6, 405-422.

Ambelu, G. (2016). Community based ecotourism development in Ethiopia: Practices, challenges and prospects. LAP LAMBERT Academic Publishing.

Asfaw, A. (2014). Ecotourism as a viable strategy for livelihood diversification and sustainable natural resource management in Ethiopia (from eco-development paradigm point of view). Journal of Environmental Science and Water Resources, 3(2), 40-52.

Ashenafi, Z., Coulson, T., Silero-Zubiri, C., \& Leader-Wiliams, N. (2005). Behavior and ecology of the Ethiopian wolf in a human-dominated landscape-outside protected areas. Journal of Animal Conservation, 8, 1-9.

Ashenafi, Z., \& Leader-Williams, N. (2005). Indigenous common property resource management in the Central Highlands of Ethiopia. Human Ecology, 33(4), 539-563.

Ashenafi, Z., \& Leader-Wiliams, N. (2006). The resilient nature of common property resource management system: Case study central highlands of Ethiopia. In The 12 international conference of international association for the study of common property resources, Bali, Indonesia.

Ashenafi, Z., Leader-Williams, N., \& Coulson, T. (2012). Consequences of human land use for an Afro-alpine ecological community in Ethiopia. Conservation and Society, 10(3), 209-216.

Asker, S., Carrard, N., \& Paddon, M. (2010). Effective community based tourism: A best practice manual. In Centre STCR (Ed.), APEC Secretariat: Griffith University, Australia.

Aynalem, Y., \& Afework, B. (2018). Diversity, distribution and habitat association of birds in Menze-Guassa Community Conservation Area, Central Ethiopia. International Journal of Biodiversity and Conservation, 10(9), 372-379.

Aynalem, S., \& Simane, B. (2016). Development of community-based ecotourism: A case of choke mountain and its environs, Ethiopia—Challenges and opportunities. Journal of Tourism, Hospitality and Sports., 16, 1-18.

Bekele, H., Teshome, E., \& Asteray, M. (2017). Assessing protected areas for ecotourism development: The case of Maze National Park, Ethiopia. Journal of Hospitality Management and Tourism, 8(3), 25-31.

Berhanu, K., \& Teshome, E. (2016). Opportunities and challenges for wildlife conservation: The case of Alatish National Park, Northwest Ethiopia. African Journal of HospitalityTourism and Leisure., 7(1), 1-13.

Coria, J., \& Calfucura, E. (2012). Ecotourism and the development of indigenous communities: The good, the bad, and the ugly. Ecological Economics, 73, 47-55.

CSA. (2007). Population and housing census of Ethiopia. UNSAD.

Denman, R. (2001). Guideline for community-based ecotourism development. Gland, Switzerland.

Eshetu, A. (2014). Ecotourism as a viable strategy for livelihood diversification and sustainable natural resource management in Ethiopia (from eco-development paradigm point of view). Journal of Environmental Science and Water Resources., 3(2), 40-52.

EWNHS. (1996). Important bird areas of Ethiopia. Published in Addis Ababa: Ethiopia.

Fennell, D. A. (2001). A content analysis of ecotourism definitions. Current Issues in Tourism., 4(5), 403-421.

Fentaw, T. (2016). Potentiality assessment for ecotourism development in Dida Hara Conservation site of Borena National Park, Ethiopia. International Journal of Tourism \& Hospitality Reviews, 3(1), 1-16.

FZS. (2007). The community-managed Guassa Area, Menz: General Management Plan, 2007-2012. In: Society FZ (Ed.), The darwin initiative, and the Ethiopian Wolf Conservation Programme.

Gebreigziabher, A. (2015). An assessment of potential resources of tourism development in Ethiopia: The case of Dejen Wereda. African Journal of History and Culture, 7(4), $1-15$.

Giampiccoli, A., \& Saayman, M. (2017). Community-based tourism, responsible tourism, and infrastructure development and poverty. African Journal of Hospitality, Tourism and Leisure, 6(2), 1-28.

GMP. (2007). The community-managed Guassa Area Menz: General management plan 2007-2012. Compiled and edited, with the support of the Amhara National Regional State, by Frankfurt Zoological Society.

Hardy, A. L., \& Beeton, R. J. S. (2001). Sustainable tourism or maintainable Tourism: Managing resources for more than 
average outcomes. Journal of sustainable Tourism, 9(3), $168-192$.

Kidane, A. (2012). Community based ecotourism development: The case of Guassa in North Shewa, Ethiopia. A Thesis Submitted to Center for Environment, Water and Development Studies Program of Tourism and Development: Addis Ababa University.

Kiss, A. (2004). Is community-based ecotourism a good use of biodiversity conservation funds? Trends in Ecology \& Evolution, 19(5), 232-236.

Knerr, B. (2008). Ecotourism as a tool for sustainable rural community development and natural resource management.

Kothari, A. (2013). Communities, Conservation and Development. Journal of Biodiversity, 14(4), 223-226.

Mamo, G., \& Wube, T. (2018). Local people's attitude and the impact of community-based conservation practice at Menz-Guassa community conservation area, Ethiopia. Developing Country Studies, 8(9), 1-8.

Mandefero, M., \& Tilaye, W. (2019). Variability in group size and daily activity budget of family groups of the gelada baboon (Theropithecus gelada) at Guassa community conservation area, Central Ethiopia. Journal of Ecology and Environment, 43, 1-8.

Manu, I. K., \& Wuleka, J. C. (2012). Community-based ecotourism and livelihood enhancement in Sirigu, Ghana. International Journal of Humanities and Social Science, 2(18), 1.

Mensa, I. (2017). Benefits and challenges of community-based ecotourism in park-fringe communities: The case of Mesomagor of Kakum National Park, Ghana. Tourism Review International, 21, 81-98.

Meskele, T. A., Woreta, L. S., \& Gebrewold, E. (2016). Accessible tourism challenges and development issue in tourist facilities and attraction sites of Amhara region world heritage sites, Ethiopia. Journal of Tourism Challenges and Trends, 9(2), 5-15.

Nelson, F. (2004). The evolution and impacts of community based ecotourism in Northern Tanzania. London: International Institute for Environment and Development.

Pearce, DG. (1992). Potentials and problems in the development of tourism. In V. L. Smith \& W. R. Eadington (Eds.), Philadelphia, PA: University of Pennsylvania Press.

Razzaq, A. R. A., Mustafa, M. Z. M., Hassan, A. S., Hassan, R., Hamzah, A., \& Khalifah, Z. (2012). Community capacity building for sustainable tourism development: experience from Miso Walai home stay. Business and Management Review, 5, 10-19.

Responsible Ecological Social Tour (REST). (1997). Community based tourism handbook-Community-based tourism: Principles and meaning.

Sakata, H., \& Prideaux, B. (2013). An alternative approach to community-based ecotourism: A bottom-up locally initiated non monetised project in Papua New Guinea. Journal of Sustainable Tourism, 21(6), 880-899.
Scheyvens, R. (1999). Ecotourism and the empowerment of local communities. Journal of Tourism management., 20, 245-249.

Stone, L. S., \& Stone, M. T. (2011). Community-based tourism enterprises: challenges and prospects for community participation; Khama Rhino Sanctuary Trust, Botswana. Journal of Sustainable Tourism, 19(1), 97-114.

Strydom, A. J., \& Mangope, D. (2018). Lessons learned from successful community-based tourism case studies from the global south. African Journal of Hospitality, Tourism and Leisure, 7(5), 1-13.

Tesfaye, S. (2017). A review paper on challenges and opportunities for communit based ecotourism development in Ethiopia. Journal of Tourism, Hospitality and Sports, 30, 2312-5179.

Teshome, E. (2018). Wunania Kosoye natural attraction, Ethiopia: Conservation values and their relevance to community based ecotourism. Journal of Hospitality Management and Tourism., 9(2), 14-24.

Teshome, E., \& Demissie, E. (2018). The characteristics, length of stay and motivation of foreign tourists who visit Simien Mountains National Park, World Heritage Site, Ethiopia. African Journal of Hospitality, Tourism and Leisure, 7(2), $1-15$.

Teshome, E., Woreta, S. L., \& Meskela, T. A. (2018). Challenges of tourism destination development in the Amhara National Regional State, Ethiopia. African Journal of Hospitality, Tourism and Leisure., 7(3), 1-16.

Teshome, E., Worku, A., \& Astery, M. (2015). Community based ecotourism as a tool for biodiversity conservation in Wunania-Kosoye natural attraction site, Ethiopia. Ethiopian Renaissance Journal of Social Sciences and the Humanities, 2, 28-42.

Timmothy, D. J. (2002). Tourism and community development issue. In IRSDJT (Eds, UK: Channel View Publication.

UNDP. (2012). Guassa-Menz community conservation area, Ethiopia. New York.

UNWTO. (2013). World tourism organization annual report 2012. UNWTO Madrid.

Wodaj, H., Kelbesa, E., \& Woldu, Z. (2016). Floristic composition and herbaceous aboveground dry weight biomas of Afroalpine vegetation in Guasa community conservation area, North Shewa, Ethiopia. International Research Journal of Biological Sciences., 5(1), 26-36.

Yanes, A., Zielinski, S., Cano, M. D., \& Kim, S. (2019). Community-based tourism in developing countries: A framework for policy evaluation Andrea. Sustainability, 11, 2506.

Publisher's Note Springer Nature remains neutral with regard to jurisdictional claims in published maps and institutional affiliations. 